\author{
А. І. Харук \\ Національна академія сухопутних військ імені гетьмана Петра Сагайдачного, \\ Львів, Украӥна
}

\title{
ЛІТАК «ВУАЗЕН ІВАНОВА»: ДОКУМЕНТАЛЬНА ІСТОРІЯ МОДЕРНІЗАЦЇ̈, ВИРОБНИЦТВА І СЛУЖБИ
}

\author{
E-mail: andrij.kharuk@gmail.com \\ ORCID: https://orcid.org/0000-0003-3459-1657 \\ Researcher ID: https://publons.com/researcher/AAA-2516-2020/
}

Анотація. Висвітлено спробу модернізації літака «Вуазен» (французького проєкту), зроблену в 1916 р. самодіяльним авіаконструктором Петром Івановим. На підставі архівних джерел проаналізовано хід і результати льотних випробувань «Вуазена Іванова», впровадження його у серійне виробництво на заводі «Анатра» в Одесі та застосування на фронті. Визначено, що зміни, внесені Івановим у конструкцію «Вуазена», поліпшили льотні характеристики аероплана, насамперед, швидкість і швидкопідйомність. Однак маневреність стала гіршою, постраждали і його експлуатаційні характеристики. Обсяг внесених змін був настільки значним, що фактично означав створення нового літака. У підсумку переробка вже виготовлених «Вуазенів» у новий варіант виявилась недоцільною. Налагодження виробництва «Вуазенів Іванова» на заводі «Анатра» призвело до значних витрат часу й матеріальних ресурсів. Починаючи з вересня $1916 \mathrm{p}$. підприємство виготовило 100 літаків «Вуазен Іванова». Досвід експлуатації їх на фронті показав, що для 1917 р. характеристики цих машин були надто низькими і поступались навіть немодернізованим «Вуазенам». Тобто спроба модернізації літака, зроблена П. Івановим, однозначно виявилась невдалою.

Ключові слова: Перша світова війна, літак, «Анатра», «Вуазен», модернізація.

\section{A. I. Kharuk}

Hetman Petro Sahaydachny National Army Academy, Lviv, Ukraine

\section{AIRPLANE «VOISIN OF IVANOV»: A DOCUMENTARY HISTORY OF MODERNIZATION, PRODUCTION AND SERVICE}

\footnotetext{
Abstract. During the First World War, the aviation industry of the Russian Empire mainly produced copies of French aircraft of various types. Thanks to this, it was possible to save significantly on design and engineering work, introducing already tested models of aircraft into production and troops. However, on the other hand, there was an inevitable lag: modern aircraft at the time of their appearance on the Western Front, had become obsolete by the time of the establishment of their production in the factories of the Russian Empire. To this should be added the chronic disruption of contract terms, which were, rather, not the exception but the rule. As a result, air units at the front received physically new, but morally obsolete aircraft, unable to withstand the best equipment of the enemy in battle. An attempt to find a solution to this problem was the modernization of licensed aircraft, which was carried out by frontline aviators without any consent of the manufacturers. Lieutenant Petro Ivanov, a pilot of the 26th Corps Air Detachment, achieved the most success. Modified according to his project, «Voisin» was even introduced into serial production.
} 
«Voisins of Ivanov» were produced by Anatra at its plant in Odessa. Production of these aircraft began in September 1916, and a total of one hundred copies were made. The «Voisins of Ivanov» entered the front lines at the end of 1916. The experience of using them in combat actions was not very successful. The advantage in some parameters demonstrated by the prototype during the tests was not confirmed during the service at the front.

The attempt of amateur aircraft designer Peter Ivanov in 1916 to modernize the reconnaissance aircraft «Voisin» can not be considered successful. On the one hand, the solutions proposed by Ivanov allowed to somewhat improve the flight characteristics of the aircraft (speed and lift). However, the maneuverability of the aircraft and its operational characteristics deteriorated. In addition, the amount of changes made by the designer was so significant that it actually led to the creation of a new aircraft. As a result, the conversion of «Voisins» into a new version was impractical. The introduction of «Voisin of Ivanov» into production at the Anatra plant led to significant expenditures of time and material resources. The experience of operating the «Voisin of Ivanov» aircraft at the front showed that for 1917 their characteristics were too low. They were inferior even to the unmodernized «Voisins».

Keywords: First World War, aircraft, Anatra, Voisin, modernization.

Вступ. У роки Першої світової війни авіаційна промисловість Російської імперії переважно випускала копії французьких літаків різних марок - «Фарман», «Моран», «Ньюпор», «Вуазен». Завдяки цьому вдавалось суттєво заощаджувати на проектноконструкторських роботах, впроваджуючи у виробництво і у війська вже перевірені взірці авіатехніки. Однак з іншого боку неминучим було відставання: літаки, сучасні на момент своєї появи на Західному фронті, встигали застаріти до часу налагодження їх випуску на заводах Російської імперії. До цього слід ще додати хронічні зриви контрактних термінів, які були, швидше, не винятком, а правилом. У підсумку авіаційні загони на фронті отримували фізично нові, але морально застарілі аероплани, неспроможні протистояти в бою кращій техніці ворога. Спробою вирішити цю проблему стала модернізація ліцензійних літаків, яка проводилась фронтовими авіаторами без жодної згоди фірм-виробників. Найбільшого успіху досягнув підпоручик Петро Іванов, пілот 26-го корпусного авіазагону (КАЗ). Допрацьований за його проектом «Вуазен» навіть був впроваджений у серійне виробництво.

Історія «Вуазена Іванова» (скорочено - «В.І.») цікава для українських дослідників, зокрема, й тим, що літак цей випускався в Одесі, на авіаційному заводі «Анатра». Однак, незважаючи на те, що епопея з випуском «В.І.» тривала понад рік і виготовлено було сто таких біпланів (немала цифра для реалій того часу), історія створення і виробництва «Вуазена Іванова» досі висвітлена лише фрагментарно. У класичних працях П. Дузя та В. Шаврова цьому літакові відведено лише одну-дві сторінки $[2$, с. 51-52; 13, с. 177-178]. Роботи авторитетних зарубіжних дослідників Дж. Давілли та А. Солтана, а також П. Варріале містять згадки про виробництво і службу літаків «Вуазен» в Росії, однак в них взагалі не згадується їх модернізація [1, с. 542-544; 14, с. 39-40]. Автор у своїх публікаціях теж звертався до проблеми створення, виробництва і застосування літаків «В.І.» [3, с. 12-13; 4, с. 243-255; 5, с. 36-37]. Однак пошуки в архівних фондах дозволили уточнити деякі важливі деталі історії створення «Вуазена Іванова» та випуску таких літаків.

Матеріал і методи дослідження. Основним методом, застосованим під час роботи над статтею, є метод джерелознавчого аналізу. Джерельну базу дослідження склали матеріали фондів 493 і 2008 Російського державного військово-історичного архіву.

Результати та обговорення. Літаки «Вуазен» - типові для французької конструкторської школи одномоторні двомісні біплани зі штовхаючим гвинтом становили значну частину парку російської армійської авіації періоду Першої світової війни. За ліцензією їх випускали заводи Лебедєва (Петроград), «Дукс» (Москва) та «Анатра» (Одеса). Загалом російська авіація отримала близько 400 аеропланів цієї марки [4, с. 251]. Найбільш поширеною була модель LAS, яка обладнувалась радіальним двигуном рідинного охолодження «Сальмсон» потужністю 140 або 150 к. с. Цей літак відзначався значною тривалістю польоту (до 4 годин) і вантажопідйомністю (до 200 кг бомб). Однак швидкість «Вуазена» LAS не перевищувала 110-115 км/год [1, с. 542]. 
Для 1916 р. цього було абсолютно недостатньо. Усунути цей недолік і спробував Петро Іванов.

Переробку звичайного серійного літака у «Вуазен Іванова» виконали в ініціативному порядку навесні 1916 р. За умови збереження попереднього двигуна збільшити швидкість можна було лише шляхом зменшення маси літака. На досягнення цієї мети і спрямував свої зусилля П. Іванов. Випробування машини проводились в Одесі. 23 травня (5 червня) великий князь Олександр Михайлович, який обіймав посаду завідувача авіацією і повітроплаванням діючої армії, відправив в Управління Військового Повітряного Флоту (УВПФ) телеграму щодо підсумків випробувань «Вуазена Іванова». У ній вказувалось, що літак 3 двигуном «Сальмсон» потужністю 140 к. с. показав швидкість 130 км/год і кращу, ніж у базової машини, швидкопідйомність. Олександр Михайлович рекомендував припинити виготовлення в Одесі літаків «Вуазен», а натомість перейти до випуску удосконалених «В.І.». Пропонувалось у новому варіанті виготовити 125 літаків 3200 «Вуазенів», замовлених «Анатрі», а вже виготовлені вузли і деталі, які не можна застосувати на «В.І.», використати як запасні частини для «Вуазенів» $[6$, c. 63-64].

2 (15) червня великий князь надіслав до УВПФ більш грунтовного листа, до якого додав акт випробувань «Вуазена Іванова», проведених 28-30 квітня (11-13 травня) 1916 p. [6, с. 78-82]. В акті зазначалось, що «В.І.» 3 мотором «Сальмсон» потужністю 140 к. с. важить (без палива і води) 850 кг, а «Вуазен» - 940 кг. 3 іншого боку, баки «В.І.» вміщали 160 кг бензину, а «Вуазена» - майже на 100 кг більше. Конструкція біпланної коробки «В.І.» завдяки зробленим Івановим удосконаленням була міцнішою, а гондола полегшеною і більш обтічної форми. Значно полегшеним було і шасі, в якому пружинні амортизатори замінили гумовими, а стійки і підкоси зробили овальними в перерізі, а не круглими. Основні зауваження комісії стосувались конструкції хвостового оперення. В акті зазначалось, що зміни, внесені Івановим у стабілізатор і стерно напряму знизили стійкість літака. Тому комісія рекомендувала повернутись до «вуазенівської» конструкції оперення. Порівняльні льотні випробування показали значну перевагу «В.I.». Його максимальна швидкість сягала 127 км/год, а для «Вуазена» цей показник становив 112 км/год. Літак «В.І.» 3 повним навантаженням набирав висоту 2100 м за 20 хв, а «Вуазен» піднімався на 2000 м за 24 хв. Загальні висновки комсії полягали у такому:

- «В.І.» переважає «Вуазен» за швидкістю, швидкопідйомністю і міцністю біпланної коробки;

- у представленому на випробування вигляді «В.І.» поступається «Вуазену» стійкістю на віражах;

- інші льотні й експлуатаційні характеристики «В.І.» аналогічні «Вуазену»;

- слід дообладнати «В.І.» кулеметною установкою та гальмами коліс.

1-3 (14-16) травня випробування прототипа продовжились. На літак встановили стерно напрямку від «Вуазена», після чого стійкість машини в повітрі покращилась [6, c. 87].

21 травня (6 червня) в Одесі пройшов черговий тур випробувань прототипа «B.I.», вже обладнаного кулеметною установкою. Пілотував машину командир 32-го корпусного авіаційного загону поручик Попов. Висновки його загалом збігались з висновками попередньої комісії: «В.І.» переважає «Вуазена» за швидкістю, а за іншими показниками, як мінімум, не поступається йому [6, с. 69-69зв.].

Питання про виробництво «Вуазенів Іванова» в Одесі порушувалось ще раніше. 7 (20) травня 1916 р. канцелярія великого князя Олександра Михайловича отримала від власника підприємства Артура Анатри доволі детальний лист [6, с. 66-66зв.]. У ньому зазначалось, що з точки зору технології «В.І.» $є$ новим типом літака, а не модифікацією існуючого. На підтвердження цього Анатра додав до листа таблицю, підписану П. Івановим, яка містила перелік вузлів «В.І.» 3 поділом на три категорії: ті, які можна взяти від «Вуазена» у незмінному вигляді; ті, що потребують переробки; які слід виготовляти заново [6, с. 67]. 3 неї випливало, що основні вузли - гондола фюзеляжу, шасі, крила та їх кріплення - мають виготовлятись заново. Підприємець 
стверджував, що переробка «Вуазенів» у «В.І.» неможлива, але погоджувався на заміну замовлення на ще не виготовлені літаки. За його словами, на це потрібно було два місяці часу.

10 (23) травня Артур Анатра телеграмою висловив свою згоду на заміну замовлених «Вуазенів» літаками «В.І.» за ціною 13500 рублів за одиницю [6, с. 65]. Ця ціна була у той час в Російській імперії стандартною для двомісних одномоторних бойових літаків; вона не включала двигун, повітряний гвинт і озброєння, які купувались УВПФ за окремими контрактами.

Великий князь Олександр Михайлович наполягав на тому, щоб якомога швидше розпочати виробництво «В.І.». 3 (16) червня 1916 р. він відправив телеграму генералу М. Пневському (начальникові УВПФ): «Желательно не дожидаясь решения Исполнительной Комиссии приказать Анатре начать постройку измененных Вуазенов» (цит. мовою оригіналу) [6, с. 83]. Відповідь Пневського була досить виваженою в телеграмі від 9 (22) червня він вказував, що видача замовлення до рішення Воєнної Ради чи Виконавчої Комісії можлива тільки з відома військового міністра, а йому в доповіді необхідно вказати узгоджені з Анатрою умови перезамовлення [6, с. 84]. Зрештою, воля великого князя поступилась вимогам бюрократії. 25 червня (8 липня) 1916 р. фірма «Анатра» офіційно підтвердила згоду замінити 100 ще не виготовлених літаків «Вуазен» такою самою кількістю «В.І.» 3 терміном поставок 30 літаків у вересні, 30 - у жовтні і 40 - у листопаді 1916 р. [6, с. 88].

Перші п’ять літаків «В. І.» завод здав військовим 27 вересня (10 жовтня) 1916 р. $[10$, c. $53 \mathrm{a}]$. Було зрозуміло, що у визначені контрактом терміни вкластись не вдасться. Замовник визнав, що зрив термінів був зумовлений затримками 3 доопрацюванням конструкції літака. Тому 5 (18) жовтня фірма отримала відстрочку: термін готовності 30 літаків зсувався на листопад, а останніх 40 - на грудень 1916 р. [6, с. 97]. Назагал же ставлення військових до «Анатри» не можна назвати надто прихильним. Внаслідок заміни 100 замовлених літаків «Вуазен» LAS на таку саму кількість «В.І.» на фірмі залишилось багато заготовлених деталей «Вуазенів», які не можна було використати для виготовлення «В. І.». А. Анатра пропонував військовим викупити ці деталі як запчастини для раніше виготовлених «Вуазенів». Ця пропозиція була підтримана великим князем Олександром Михайловичем. Однак 5 (18) січня 1917 р. УВПФ 3 огляду на відсутність потреби відмовилось купувати ці деталі [8, с. 25-25зв.]. 3 огляду на внесені в конструкцію літака зміни, Анатра звернувся з проханням збільшення контрактної ціни «В.І.» на 1000 крб. за одиницю. Військове відомство, навіть визнаючи факт втрати фірмою 720 крб. на кожному модифікованому літакові, наполягло на збереженні попередньої ціни! [7, с. 19-20].

22 січня (4 лютого) 1917 р. старший авіаційний прийомщик Південного району капітан Саатчі-Самадчі доповідав, що усі сто літаків «В.І.» (серійні номери 527-626) виготовлені. Однак через брак моторів вдалось випробувати в польоті і відправити в армію лише 44 аероплани [7, с. 92]. За умовами контрактів (типовими для усіх закупівель авіаційної техніки) фірма відповідала за виготовлення планерів літаків, а двигуни і повітряні гвинти купувались військовим відомством за окремими угодами. Відповідальність за їх своєчасне постачання на авіазаводи покладалась на УВПФ. На «В.І.» встановлювались мотори «Сальмсон» потужністю 150 к. с., які постачались із Франції або випускались московською філією французької фірми. Однак подолати хронічний «моторний голод» не вдавалось. У підсумку останні з передбачених контрактом літаків «В.І.» були «прийняті в казну» лише 17 (30) червня 1917 р. [10, c. 138]. До того ж майже третину з них прийняли у квітні - червні 1917 р. [11, с. 50-55]. Тобто відставання від контрактних термінів становило приблизно півроку. Та це ще було не все: 1 (14) грудня 1917 р. «в казну» прийняли додатковий, 101-й, літак «В.І.». Заява підприємства щодо оплати цього виробу послужила приводом для службового розслідування - на якій підставі прийомщик видав посвідчення про приймання літака, не передбаченого контрактом. Відповідне розпорядження видали 9 (22) січня 1918 р. [8, с. 477]. Однак документи про результати цього розслідування поки не виявлені. 
Якість літаків «В.І.», переданих у війська, була не найкращою. Свідченням цього може бути хоча б рапорт штабс-капітана Лівотова, командира 35-го КАЗ (входив до 13-го авіаційного дивізіону Особливої армії Південно-Західного фронту) від 18 лютого (3 березня) 1917 р. [8, с. 173-174зв.]. Перелік недоліків для п’яти літаків «В.І.», отриманих загоном із заводу, містив 12 пунктів: розрегульованість усіх апаратів, корозія низки вузлів, некомплект запасних частин, відсутність формулярів і схем регулювання тощо. На одному з літаків довелось замінити погнуту задню вісь шасі, однак і нова деталь через день погнулась, хоч літак увесь час перебував на стоянці очевидно, вона була виготовлена 3 надто м'якої сталі. Випробування «В.І.» в польоті, проведені у 35-му КАЗ, показали, що він дещо переважає стандартний «Вуазен» за швидкістю і швидкопідйомністю. Однак, на думку Лівотова, вирішального значення це не мало. А ось гірша маневреність «В.І.» вважалась серйозним недоліком, бо це робило літак непридатним для коригування артилерійського вогню. Висновок Лівотова був невтішний: удосконалений літак виявився навіть гіршим порівняно 3 «Вуазеном». 23 березня (4 квітня) А. Анатра надіслав розлогого листа з відповідями на зауваження Лівотова [8, с. 229-232]. Визнаючи частково провину підприємства, Анатра разом 3 тим стверджував, що низка недоліків «В.І.» зумовлена особливостями конструкції цього літака - на що, мовляв, він вказував ще під час перших випробувань прототипа.

Рапорт штабс-капітана Лівотова був не першим і далеко не єдиним свідченням непридатності літаків «В.І.» для фронтової служби. Інспектор авіації армій ПівденноЗахідного фронту підполковник Ткачов у своїй доповіді від 10 (23) лютого 1917 р., складеній за підсумками відвідання авіаційних загонів, присвятив цьому літакові півсторінки. Уся доповідь займає трохи більше двох сторінок [9, с. 62-63], і жодному іншому літакові не відведено в ній стільки місця. Посилаючись на думку авіаторів, Ткачов зазначає, що невелика перевага «В.І.» у швидкості порівняно зі звичайним «Вуазеном» не поліпшує його здатність до повітряного бою через гіршу маневреність і важке управління. У доповіді згадується катастрофа «В.І.» в 26-му КАЗ, причиною якої стали конструктивні недоліки аероплана. Ткачов зазначає, що до літаків «В.І.» пілоти ставляться 3 великою недовірою і наполягає на якомога швидшому вилученні цих аеропланів з фронтових частин. Як альтернативу він пропонує літаки «Фарман» XXX i «Анаде». Однак з огляду на гостру нестачу аеропланів задовольнити побажання Ткачова було неможливо, i «Вуазени Іванова» продовжували надходити на фронт.

На фронті перші «Вуазени Іванова» 3’явились наприкінці 1916 р. Основними їх експлуатантами стали корпусні авіаційні загони. Станом на 1917 р. такий загін за штатом включав десять літаків: шість розвідників, два винищувачі і два коректувальники [2, с. 240]. Пара літаків-коригувальників у складі загону утворювала артилерійське відділення. Саме у ці відділення і надходили у першу чергу літаки «В.I.». Траплялись і винятки - вище ми вже згадували про 35-й КАЗ, який отримав одразу п’ять таких аеропланів. Крім того, «В.І.» надійшли до 1-го Сибірського (два літаки) і 5-го Сибірського (три) корпусних авіазагонів, 9-го, 15-го, 21-го, 24-го, 25-го, 26-го, 50-го КАЗ. Отримали їх також 4-й і 12-й армійські авіаційні загони. Значна частина «Вуазенів Іванова» осіла на складах, так і не потрапивши на фронт. Наприклад, дислокований у Вітебську 4-й авіапарк у січні 1918 р. мав на складі сім не вживаних літаків «В.I.» [4, с. 254-255].

Для оцінки «Вуазена Іванова» 3 точки зору стройового пілота суттєвий інтерес становлять два документи, підписані командиром 26-го КАЗ, капітаном Антоновим: акт випробування від 4 (17) березня 1917 р. [12, с. 29] і доповідна записка, складена не пізніше 3 (16) серпня 1917 р. [12, с. 57]. У цих документах Антонов зазначає, що перевага «В.І.» над «Вуазеном» у швидкості зумовлювалась більшою потужністю двигуна (150 к. с. порівняно зі 140 к. с.). Поява ж на фронті «Вуазенів» 3 двигунами потужністю 150 к. с. звела цю перевагу нанівець. Серед недоліків «В.І.» Антонов головним вважає низьку поперечну стійкість. Ї̈̈ намагались поліпшити, встановивши на літак елерони збільшеного розміру. Хоч Антонов і вказує на недоліки «Вуазена Іванова», у своїх висновках він не настільки категоричний, як Ткачов: «...при усилении шасси и увеличении крыла самолёты ВИ годятся для работы на фронте, но требуют 
большой осторожности на малой высоте и опытности лётчиков» (цит. мовою оригіналу) [12, c. 57$]$.

Висновки. Спробу самодіяльного авіаконструктора Петра Іванова у 1916 р. модернізувати літак-розвідник «Вуазен» назагал не можна визнати вдалою. 3 одного боку, запропоновані Івановим рішення дозволили дещо поліпшити льотні характеристики літака (швидкість і швидкопідйомність). Однак при цьому погіршилась маневреність аероплана та його експлуатаційні характеристики. До того ж обсяг внесених конструктором змін виявився настільки значним, що фактично призвів до створення нового літака. У підсумку переробка «Вуазенів» у новий варіант виявилась недоцільною. Впровадження ж «Вуазенів Іванова» у виробництво на одеському заводі «Анатра» призвело до значних витрат часу й матеріальних ресурсів. Досвід експлуатації літаків «В.І.» на фронті показав, що для 1917 р. їх характеристики були надто низькими. Вони поступались навіть немодернізованим «Вуазенам».

\section{REFERENCES}

1. Davilla, J. J. \& Soltan, A. M. (1997). French Aircraft of the First World War. Stratfod: Flying Machines Press, 614 p.

2. Duz', P. D. (1989). Istorija vozduhoplavanija i aviacii v Rossii [The history of aeronautics and aviation in Russia]. Moscow: Mashinostroenie, 336 s. (in Russian).

3. Haruk, A., Kondrat'jev, V., Hajrulin, M. (2008). «Anatra»: Litaky Odes'kogo aviabudivnogo pidpryjemstva. 1910-1924 rr. [«Anatra»: Planes of the Odessa aircraft-building enterprise. 1910-1924]. Kyi’v. Tempora, 80 s. (in Ukrainian).

4. Haruk, A. I. (2014). Litaky «Vuazen»: rozvytok, vyrobnyctvo ta zastosuvannja v Ukrai'ni [Voisin aircraft: development, production and application in Ukraine]. Viyskovo-naukovyi Visnyk, 22, 249-259 (in Ukrainian).

5. Haruk, A. I. (2008). Proizvodstvennaja dejatel'nost' firmy «Anatra» [Production activities of the company «Anatra»]. Aviatsiya $i$ Vremya, 1, 36-39 (in Russian).

6. Rosijs'kyj derzhavnyj Vojenno-istorychnyj arhiv (PDVIA) [Russian State Military Historical Archive (RSMHA)]. F. 493. In. 4. C. 66. 160 p. (in Russian).

7. PDVIA [RSMHA]. F. 493. In. 4. C. 119. 708 p. (in Russian).

8. PDVIA [RSMHA]. F. 493. In. 4. C. 388.575 p. (in Russian).

9. PDVIA [RSMHA]. F. 493. In. 4. C. 414.744 p. (in Russian).

10. PDVIA [RSMHA]. F. 493. In. 11. C. 80. 139 p. (in Russian).

11. PDVIA [RSMHA]. F. 2008. In. 1. C. 356.311 p. (in Russian).

12. PDVIA [RSMHA]. F. 2008. In. 1. C. 555. 159 p. (in Russian).

13. Shavrov, V. B. (1978). Istorija konstrukcij samoletov v SSSR do 1938 goda [The history of aircraft designs in the USSR until 1938]. Moscow: Mashinostroenie, 576 s. (in Russian).

14. Varriale, P. (2009). Voisin III/V at war. Berkhamsted: Albatros Productions Ltd., 40 p.

Received 16.08.2020

Accepted 15.09.2020 